Yönetim, Ekonomi, Edebiyat, İslami ve Politik Bilimler Dergisi,4(1): 153171, 30 Haziran-June, 2019
JOMELIPS - Journal of Management

Economics Literature Islamic and

Political Sciences

e-ISSN :2547-9512

\title{
Sağlık İşletmelerinde Performans Değerlendirme ve Ölçme Yöntemleri Hakkında Bir Derleme Çalışması
}

\author{
Mesut Karaman* \\ Kahramanmaraş Sütçü İmam Üniversitesi Sosyal Bilimler Enstitüsü, Sağlık Yönetimi \\ Anabilim Dal1, mesut_karaman66@hotmail.com
}

\begin{abstract}
Hilal Kuşcu Karatepe
Osmaniye Korkut Ata Üniversitesi Sağlık Yüksekokulu Hemşirelik Bölümü, hkuscukaratepe@osmaniye.edu.tr
\end{abstract}

Fatma Nuray Kuşcu

Mustafa Kemal Üniversitesi Sağlık Hizmetleri Meslek Yüksekokulu, nuraykuscu@outlook.com

\section{Öz}

Sağlık hizmetine olan talep her geçen gün artmakta bu doğrultuda da sağlık hizmeti veren kuruluşların sayısı yükselmektedir. Bu yeni kurulan veya daha da büyümeyi hedefleyen bir sağlık kurumlarının istenilen seviyeye gelebilmesi için etkin bir performans yönetimini sağlamaları gerekmektedir. Performans değerlendirme sayesinde sağlık kurumlarında, belirlenen amaçlar ve hedefler doğrultusunda gerçekleştirilen faaliyetlerin sonuçlarının belirlenmesi, ölçülmesi, yapılan planlarla karşılaştırılması, sonuçların değerlendirilmesi ve bu sayede geleceğe yönelik karar alınması sağlanabilir. Bu yönüyle performans değerlendirme büyük önem taşımaktadır. Sağlık kurumlarında belirlenen amaçlar ve hedefler doğrultusunda gerçekleştirilen faaliyetlerin sonuçlarının tanımlanabilmesi, ölçülmesi, yapılan planlarla karşılaştırılması, sonuçların değerlendirilmesi, geleceğe yönelik karar alma yönüyle birer kaynak olması sebebiyle performans değerlendirmesi büyük önem taşımaktadır. Performans yönetiminin kurumda etkin bir biçimde uygulanabilmesi için çalışanların algılayabileceği düzeyde olması gerekmektedir ve herkesin katılımı sağlanmalıdır. Sağlık kurumunun sunduğu hizmetin niteliğine göre performans 
değerlendirme yöntemini seçmesi gerekmektedir. $\mathrm{Bu}$ çalışma performans değerlendirme yöntemleri hakkında alan yazınına katkı sağlamak amacıyla bir derleme halinde hazırlanmıştır.

Anahtar kelimeler: Performans, Performans Değerlendirme, Performans Ölçümü, Sağl1k Kurumlar1.

\title{
A Compilation Study on Performance Evaluation and Measurement Methods in Health
}

\section{Businesses}

\begin{abstract}
The demand for health services is increasing day by day and the number of institutions providing health services increases. This newly formed or a health institution which aims to further growth are required to ensure an effective performance management in order to come to the desired level. Through performance evaluation, health institutions can determine the results of the activities carried out in line with the goals and objectives determined, compare them with the plans made, evaluate the results and make decisions for the future. In this respect, performance evaluation is of great importance. Health Institutions in their designated objectives during and goals in order to identify the Consequences of actions, measuring, Comparing with the plans, evaluation of results, decision-making for the future aspect because it is a source of performance evaluation is of great Importance. In order for the performance management to be effectively implemented in the organization, employees must be at the level that employees can perceive and everyone should be involved. The health institution should choose the performance evaluation method according to the quality of the service provided. This study was prepared in a review to contribute to the literature about performance evaluation methods.
\end{abstract}

Keywords: Performance, Performance Evaluation, Performance Measurement, Health Institutions.

\section{Giriş}

Performans değerlendirme ve performans yönetimi, yöneticilerin belirlemiş olduğu stratejik planları, amaçları ve hedefleri gerçekleştirebilmek için en çok karşılaştıkları sorunların başında gelmektedir. Örneğin, sağlık işletmeleri bulundukları bölgeye daha yüksek nitelikte ve nicelikte 
hizmet sunabilmek için tüm çalışanlarından yüksek bir performans beklemektedirler. Günümüz koşullarında yaşanan değişimler karşısında ise sağlık kurumlarında başarıyı sağlayacak fonksiyonlardan birisi performans değerlendirmedir.

Sağlık işletmelerinde performans değerlendirme, faaliyet sonuçlarını rapor haline getirme, çalışanların yaptıkları işlere yönelik eğilim tarzlarını belirleme noktasında alan uzmanlarına yönelik önemli bir kaynaktır. İşletmeler kurulurken varlığını sonsuza kadar devam ettirebilmek, kâr sağlamak gibi bir takım kuruluş ilkelerini benimseyerek var olmaktadır. Sağlık işletmeleri de aynı şekilde işletmenin kuruluş ilkelerinden biri olan varlığını sonsuza kadar devam ettirmek ilkesi doğrultusunda yol aldıkları için kurumda çalışanların performans değerlendirmesi ve ölçümü önemli unsurların başında gelmektedir.

Hizmet sektörünün önemli bir parçası olan sağlık kurumları bulundurduğu mevcut insan gücü ve tıbbi donanım kaynaklarıyla en iyi hizmeti sunmaya çalışmaktadır. Sağlık kurumları farklı teknolojik donanımlarla birlikte uzmanlaşma seviyesi yüksek kurumlardır. Sağlık alanında çeşitli uzmanlık alanlarında yetişmiş çalışanlara doğru değerlendirme yapıldı̆̆ 1 takdirde, etkin ve verimli hizmet sunmanın alt yapısı sağlanmış olacaktır.

Performans değerlendirme çalışanların işletmenin amaçlarına uygun eylemleri ölçme ve değerlendirmesine yöneliktir. Bunun yanı sıra, personeli, görev ve sorumluluklarını gerçekleştirmeleri konusunda isteklendirir. Performans değerlendirme sonucunda, yüksek performans gösteren çalışana ödül, terfi, hediye vb. verilebilir. Bu noktada, düşük performans gösteren çalışana ise cezalandırma yerine performansını arttırmaya yönelik girişimlerde bulunulmalıdır. Bu bağlamda bu çalışmada performans değerlendirme yöntemleri öncelikle genel düzeyde daha sonra sağlı kurumları yönüyle incelenmiş ve alan yazınına katkı sağlaması amacıyla ilgili literatür taraması sonucu derleme türünde hazırlanmıştır.

\section{Performans ve Performans Değerlendirme}

Performans, işletmenin belirlemiş olduğu amaçlar ve planlar doğrultusunda nicel ya da nitel olarak değer kazanmış olan kavramların bütünü olarak tanımlanmaktadır. Performans işletmenin hedeflerine ve amaçlarına ulaşmak için belirlemiş olduğu standartlar doğrultusunda çalışanlar tarafından uygun davranışların gösterilmesi ve beklenen amaçlara yaklaşma derecesi olarak da ifade edilmektedir. Performans, aynı zamanda bir çalışanın belirli bir zaman kesiti içinde kendisine verilen görevin neticesinde elde ettiği sonuçlardır (Tunçer, 2013, s. 89). 
Örgütsel davranış açısından performans incelendiğinde çalışanın örgütsel amaçları gerçekleştirmek ve belirlenen hedeflere ulaşmak için görevi ile ilgili gerçekleştirdiği işlemlerinin sonucunda elde ettiği üründür. $\mathrm{Bu}$ ürün mal, hizmet ve düşünce türünde olabilmektedir. Performansın belirlenmesi ve değerlendirilmesi için gerçekleştirilen faaliyetin sonuna bakılarak bir çıkarım sağlanmalıdır (Appelbaum, David, Nadeau \& Michael 2009, s. 13).

Performans değerlendirmesi ve performans ölçümü birbirleriyle ilgili kavramlardır fakat farklı ifadeleri içermektedirler. Değerlendirme, işlem sonucunda çalışanın performansını arttırmaya yönelik yapılması gereken değişiklik ve önerilerde bulunurken; performans ölçümü ise kurumun mevcut durumuyla ilgili anlık fotoğrafını çekmekte ve belirlenen amaçlara ulaşıp ulaşmadığı ile ilgili bilgiler vermektedir. Ölçüm sonuçlarına göre işletmenin başarılı ya da başarısız olarak değerlendirilmesi mümkün değildir. Kapsamlı bir performans değerlendirmesi sonucunda ise işletmeyi gerçekleştirmek istediği hedefler doğrultusunda başarılı ya da başarısız olarak nitelendirmek ve bu sonucun neden kaynaklandığı hakkında kesin sonuçlara ulaşabilmek mümkündür (Tunçer, 2013, s. 90).

Çalışanların, performans değerlendirmesi sayesinde, işletmedeki görevleri ne olursa olsun etkinlikleri, eksikleri, fazlalıkları, görevlerindeki yetersizlikleri gibi tüm yönleri değerlendirilmiş olmaktadırlar. Performans değerlendirme işleminin Türkiye'deki ilk uygulamaları kamu kesiminde başlamıştır. Uygulamanın seksen yıllık bir geçmişi vardır. Özel sektörde ise performans kavramının ancak son yirmi yılda işletme bilimi içerisinde yer aldığı, önemli hale geldiği ve modern yönetim tekniklerinin giderek artması ile gelişme gösterdiği görülmüştür (Pehlivan, 2008, s. 172). Performans değerlendirme süreci, sonunda elde edilen bilgiyle beraber, çalışanların kendilerini geleceğe yönelik geliştirmeleri sağlanmaktadır. İşletme açısından bakıldığında ise performans değerlendirme ücret düzenlemesi, terfi veya işten çıkarma gibi idari kararları verme noktasında yardımcı olmaktadır (Pehlivan, 2008, s. 173).

Her kurumun diğerlerinden farklı kendisine has bir yapıda olması nedeniyle kendine uygun bir performans değerlendirme yöntemini seçmesi ve uygulaması gerekmektedir. Seçilen performans değerlendirme yöntemleri bilimsel çerçeve içerisinde olmalı ve bu aşamada genel kabul görmüş metotlar tercih edilmelidir. Performans değerlendirme kapsamında seçilen bir yöntemin örgütsel yapıya uygun olmaması ya da başarısızlığı nedeniyle çalışanların bireysel ve örgütsel başarısının 
düşmesi aynı zamanda moral ve motivasyon kayıplarına yaşanmaktadır. Bu tür yöntemler örgütsel ve bireysel amaçları yerine getirmekte birer engel teşkil etmektedirler.

Literatürde yer alan performans değerlendirme yöntemleri aşağıda açıklanmıştır:

Grafik dereceleme yöntemi, kullanılan yöntemler içerisinde en köklü geçmişi bulunan ve en sık tercih edilen değerlendirme metodudur. Değerlendirmeciye, değerlendirmesini yapacağı her ast için bir form verilmektedir. Değerlendirmeci formda daha önceden belirlenmiş olan maddeler üzerinde değerlendirme işlemini yapar. Grafik dereceleme yöntemi literatürde ayrıca standart puanlandırma cetveli olarak da isimlendirilmektedir. (Tengilimoğlu, Işık \& Akbolat, 2012, s. $391)$.

Zorunlu seçim yönteminde, Bu yöntemde değerlemeciye, hangisinin daha yüksek puana sahip olduğunu kestiremeyeceği bir dizi ifadelerin yer aldığı bir form verilir ve personeli değerlerken bu ifadelerden birini seçmeye zorlanır. $\mathrm{Bu}$ nedenle bu yöntem zorunlu seçim yöntemi olarak adlandırılır (Tunçer, 2013, s. 97).

Karşılaştırma yöntemi, çalışanları belirli bir grup içerisinde ya da birimlerde çalışanları birbirleri ile karşılaştırarak sıralama elde eden bir yöntemdir. Karşılaştırma işlemi, yukardan aşağıya ya da soldan sağa doğru bir matris tablosuyla yapılmaktadır ve her işgörenin diğer işgörenlerle kıyaslanıp daha sonra diğer işgörene göre başarılı görülenlere “+” işareti atanmasıyla oluşan bir formdur. Kıyaslamanın en sonunda “+” sayısı toplamı fazla olandan en aza kadar işgörenlerin sıralama sayısı yazılarak form tamamlanır. Bu yöntemi kullanan işletmelerde çalışanların başarı sıralaması kolaylıkla elde edilmektedir ve bu işletmenin vereceği nihai kararların alınmasını kolaylaştırmaktadır. Karşılaştırma yöntemi, değerlendirici hatalarına açık bir yöntem olduğu gibi, aynı zamanda çalışanların birbirileriyle kıyaslanması söz konusu olduğu için motivasyon sorunları da yaratabilmektedir (Eraslan \& Algün, 2005, s. 97-98).

Zorunlu dăğllım yöntemi, değerlendiricinin değerledikleri çalışanları öznel yargılarla değerlendirme ölçeğinin herhangi bir kısmında kümelendirmelerini engellemek ve bu sebeple ortaya çıkabilecek tutarsızlıkları önlemek için geliştirilmiş bir metottur (Kocabey, 2014, s. 14). İstatistiksel olarak normal dağılım eğrisinin özelliklerinden yararlanan bu yöntem, işletmelerde küçük bir grubun başarılı veya başarısız olacağı, bunların dışında kalanların ise bu iki grup arasında kalacağı varsayımını savunmaktadır (Yıldırım, 2008, s. 44). 
Kritik olay yöntemi, değerlendirmeyi yapan kişi çalışanı iş başında gözlemleyerek onun başarılı ve başarısız yönlerini tespit ederek kayıt tutmaktadır. Bu kayıtlarda ayrıca çalışanın işe yönelik davranışlarına ve çalışma koşullarıyla ilgili tanımlara da yer verilmektedir. $\mathrm{Bu}$ metotta değerlendirme işlemi bireyin işine yönelik göstermiş olduğu davranışlar doğrultusunda yapılmaktadır. Değerlendirme döneminde ise, tutulan bu kayıtlara bakan yöneticiler çalışanlarının her birinin istenilen özellikte olup olmadığını ve performanslarını nasıl sergilediklerini belirlemektedirler (Gün, 2015, s. 73).

360 derece değerlendirmede, çalışanın performansı; işletme içerisinde birlikte çalıştı̆̆ iş arkadaşlarından en üst amirine kadar sürekli iletişimde olduğu bireylerden elde edilen bilgiler kapsamında değerlendirilir. Bazı araştırmacılar tarafından, 360 derece yöntemi sadece bir geliştirme aracı olarak görülse de bu yöntem katılımcı bir yöntemdir, aynı zamanda performans hakkında bilgi elde etmek için tüm kaynakları da olumlu yönde kullanmaktadır (Tunçer, 2013, s. 98).

Takıma dayalı performans değerlendirme, günümüzde işletmelerin takım bazlı faaliyetlere yönelmelerinden dolayı bir yöntem olarak kullanılmaya başlanmıştır. Takım çalışmalarında değerlendirme yapılırken hem takımın hem bir takım unsuru olan bireyin performans değerlendirmesi birbirinden bağımsız olarak yapılmalıdır. Uygulama yapılırken maddelerin bir kısmı kişilerin işleriyle ilgiliyken, bir kısmı da davranışlarıyla ilgili değerlendirmelerdir. Takım çalışmasında bu davranışlar performansın tanımlanması sırasında belirtilmektedir. Bu metodun en temel özellikleri rekabeti değil işbirliğini, yardımlaşmayı ve dayanışmayı sağlamasıdır (Gün, 2015, s. 72).

Davranışa dayalı değerlendirme, zorunlu seçim yöntemi ve derecelendirme yönteminin birleştirilmesi sonucu ortaya çıkmış olan bir yöntemdir. Yöntemin içeriğinde çalışanın durumunu ifade eden tek seçeneğin işaretlenmesi kuralı vardır. Değerlendirme formunun hazırlanmasında çalışanın katılımına izin verilmekte ve çalışanın formu benimsemesi sağlanmaktadır. Çalışanın yaptığı iş esas alınarak puanlamaya gidilmektedir. Bu yöntem ücret ve kariyer planlama açısından da kaynaklık sağlamaktadır. Ayrıca yöntemin geliştirilmesi uzun bir süreci kapsadığı için zaman alıcı ve maliyeti yüksek bir yöntemdir (Eraslan \& Algün, 2005, s. 97).

Alan incelemesi yönteminde, değerlendirmeyi yapacak yetkin uzman kişinin faaliyet alanına ilişkin bilgi toplaması ve topladı̆̆ı bilgilerin sonuçlarına göre değerlendirme yapması esastır. 
Değerlendirici değerlendirme yaptığı çalışana ilişkin başarı durumundan, davranışındaki olumsuzluklara kadar birçok şey hakkında bilgi toplayarak çalışanı değerlendirmektedir. $\mathrm{Bu}$ yöntemden tutarlı sonuçlar elde edilmesine rağmen uzun zamanda halledilmesi, maliyetinin yüksek olması ve uygulamada hızlı olmaması nedeniyle işletmeler tarafından çok fazla tercih edilen bir yöntem değildir (Kaynak, 2011, s. 47).

\section{Sağlık Kurumlarında Performans Değerlendirme ve Ölçüm Kriterleri}

Sağlık kurumlarında belirlenen amaçları ve hedefleri gerçekleştirmek için birey ve grup performansını geliştirmeye yönelik sistemli bir yaklaşım olan performans yönetimi, birey ve grupların sorumluluk üstlendikleri bir kültür oluşturmayı amaçlamaktadır. $\mathrm{Bu}$ amaçlar doğrultusunda; performansla ilgili olan hedeflerin belirlenmesi, yöneticilere sorumluluk verilmesi, gerçekleşen performansın ölçülmesi, gelecekle ilgili planların yapılması ve dış denetçilere performans raporunun iletilmesi şeklinde bir süreç yönetimi izlenmektedir. Performans yönetimi, sağlık yöneticilerinin çalışanlar ile ilgili aldıkları kararların gerçek verilere dayandırılması noktasında bir kaynak olmaktadır. Performans yönetimi, aynı zamanda sorunlu alanları tespit etmeye ve gelişme sağlanabilecek alanları belirlemeye yardımcı olmaktadır (Coşkun, 2009, s. 48).Sağlık sistemi içinde yer alan sağlık kurumlarında performans (Tanrıverdi ve Çiğdem, 2010, s. 116);

1. Öncelikli hedeflerin gerçekleştirilmesi, hedeflerin başarıya ulaşıp ulaşmadığı ve nasıl başarıya ulaşıldığının ölçülmesi

2. Hedefleri gerçekleştirme sırasında yararlandıkları kaynakların ölçümü

3. Kullanılan kaynakların verimli bir şekilde kullanılıp kullanılmadığının tespiti

4. Sağlık kurumlarının işlevlerinin ve hedeflerinin verimli bir şekilde başarıya ulaşmasındaki etkilerinin değerlendirilmesidir.

Performansın ölçülmesinin birçok yararı vardır: Sağlık kurumlarında; ameliyathanelerin daha verimli ve etkin kullanımı, hastane içerisinde bekleme sürelerinin kısalması, birim hasta maliyetinin düşmesi, gelir-gider akışlarının verimli işletmecilik anlayışıyla takip edilmesi, gereksiz tetkiklerin azalması, eğitim olanaklarına teşvik verilmesi ve bunların takip edilmesi, çalışan ve hasta memnuniyetinin araştırılması bu yararlar arasındadır (Kılınç, 2012, s. 45-46). Performans ölçümü sağlık kurumlarında stratejik planlar yapılmasını ve stratejik kararlar 
alınmasını ve buna bağlı olarak da kaynakların zamanında temin edilmesini ve etkin kullanılmasını sağlamaktadır. Sağlık kurumlarında performans ölçmede kullanılan ölçütler klinisyenlere ve yöneticilere kendi servislerini diğer servislerle karşılaştırma firsatı sağlamaktadır.

Sağlık sisteminde performans göstergelerinin geliştirilmesine yönelik alan itibariyle pek çok bilim adamının katkıları bulunmaktadır. Belirlenen bu performans göstergeleri üç grup içerisinde değerlendirilmektedir. Birincisi; yapısal göstergelerdir. Bunlar hastane büyüklüğü, mülkiyet yapısı, kârlılığı gibi örgüt ve örgüt içerisinde yer alan birimlerden oluşmaktadır. İkincisi olan süreç göstergeleri; koordinasyon, insan kaynakları, planlama gibi örgüt performansını geliştirecek, arttıracak ya da kontrol etmeyi sağlayacak faaliyetlerle ilgili göstergelerdir. Üçüncüsü; çıktı göstergeleridir. Bunlar sağlı hizmetlerinde kalite, hasta memnuniyeti, çalışanların tutumu, verimlilik ve finansal çıktılardır (Donabedian, 2005; Dereköy, 2012, s. 48).

Farklı bir yaklaşım olarak Fottler (1987) geliştirdiği yaklaşımda ise, çeşitli örgüt çıktılarını performans göstergelerinin bağımsız belirleyicisi olarak düşünmüştür. Fottler'in performans ölçüm kriterleri günümüz açısından değerlendirildiğinde açıklanması gereken ve hemen hemen her kurumun performans göstergesi olarak üzerinde durduğu kriterlerin başında gelmektedir. Ona göre performans için belirlenmiş olan dört kriter; sağlıkta hizmet kalitesi, hasta memnuniyeti, verimlilik ve finansal sonuçlardır (Fottler, 1987, s. 369-375; Dereköy, 2012).

Hasta memnuniyeti: Kişiden kişiye göre değişmektedir ve hastalar tarafından farklı bir biçimde algılanmakta aynı zamanda da her hastanın memnuniyet düzeyi farklı olmaktadır. Şöyle ki; sağlık işletmelerinden hizmet alan bireylerin bir takım ihtiyaçları ve beklentileri vardır. Kişinin tedavi süresi boyunca hissettiği ihtiyaçlarına ve daha önceki yaşamış olduğu deneyimlere göre kurumdan beklentileri oluşur. Her sağlık işletmesi bireylere bazı hizmet ve ürünler sunmaktadır. Bireyin beklediği hizmet ile sunulan hizmet birbirleri ile karşılaştırıldığında kişinin memnuniyet düzeyi ortaya çıkmaktadır (Tükel vd., 2004, s. 206). Hasta memnuniyeti üzerinden performans ölçümü yapmak için gelen hasta şikâyetleri, kurum içerisindeki hasta sayısı, hastaların şifai duruma kavuşma süresi, hastalara yapılan yanlış tedavi yöntemleri gibi kriterleri esas alınmaktadır (Tezcan, Yücel Hakan, Ünal Burak \& Edirne, 2014, s. 58).

Sağllkta hizmet kalitesi: Bireylere ve topluma sunulan sağlık hizmetlerinde hedeflenen sağlık göstergelerine ulaşabilecek şekilde hizmetlerin iletilmesidir (Korkmaz \& Çuhader, 2017, s. 74). 
Hizmet kalitesi hastanın, hizmet sağlayıcının performansından beklentileri ile aldıkları hizmetlere yönelik değerlendirmeler arasındaki farklılıklardır. Hasta yönüyle hizmet kalitesinden bahsedebilmek için hastanın beklentilerini karşılaması ya da aşması gerekmektedir. Sağlıta hizmet kalitesi kriterleri; hemşire ve doktor hizmeti, bakım kalitesi algısı, sağlık personeli davranışı, poliklinik birimlerine ulaşımın rahat olması, tedavi süresi boyunca toplam harcanan zaman, yemek servisi, hastane içerisindeki gürültü, odanın sıcaklığı, temizlik ve hastanenin park alanı gibi birçok unsuru içermektedir (Bilgin \& Göral, 2017, s. 153).

Sağllkta verimlilik: Performans göstergelerinin iyi düzeyde olması sonucu ortaya çıkan verimliliktir. Kaynakların ihtiyaçlara göre tam yetecek şekilde kullanılmasıyla ilişkilidir. Sağlık kuruluşunun bulundurmuş olduğu tüm kaynakları ilgilendiren bu kriter, hem bireyin hem de kurumun belirlemiş olduğu hedeflere ulaşması açısından belirleyici olarak görülmektedir. Verimlilik sağlık işletmelerinde, performansı ve çalışma koşullarını daha yüksek seviyelere taşımayı içeren tekniklerdir. Verimlilik aynı zamanda nitel ve nicel üretimin kullanılan kaynaklara oranıdır. Niteliği geliştiren araçlardan birisidir. Somut verimlilik göstergeleri; tedavi edilen hasta sayısı, hasta başına ortalama yatış süresi, enfeksiyon hızı, ölüm hızı, verilen toplam hizmet süresi olarak siralanmaktadır (Alpaslan, 2014, s. 35).

Finansal göstergelerde, temel amaç sağlık işletmelerinin mali durumu ve finansal gelişimi hakkında bilgi sağlamaktır. Finansal göstergeler, yöneticilerin veya dışardan yatırım yapmak isteyenlerin karar vermesini sağlamada, kredi veren kuruluşlara işletmenin kredi değerliliğini belirlemelerinde yardımcı olmaktadır. Toplam kâr, toplam tahakkuk, hasta günü maliyeti, net hasta geliri gibi göstergeler, hastane işletmelerinin finansal performansını izlemek amacıyla kullanılan finansal performans kriterlerinden bazılarıdır (Kıyak, Bozaykut \& Güngör, 2011, s. 1522).

\subsection{Sağlık İşletmelerinde Performans Ölçüm Yöntemleri}

Sağlık işletmelerinin etkili ve verimli sağlık hizmeti verebilmesi ve yönetici ve çalışanların ortak amaçlara ulaşabilmesi; düzenli olarak performans ölçümünün yapılmasına bağlıdır. Performans ölçümünde kullanılan metotlar; sürekli geliştirme, uygulama ve ihtiyaçlara göre yenilenmeyi içeren dinamik bir süreç içerisindedir. Performans ölçme yöntemleriyle ilgili genel bir metot bulunmamaktadır. Her ülke kendi sağlık sistemine göre farklı performans ölçüm yöntemleri uygulayabilmektedir. Bir performans ölçüm yönetiminin döngüsü şu kriterleri içerebilir: Planlama, geliştirme, test değerlendirme, uygulama, tekrar değerlendirme, gerekirse geliştirme 
aşamasına tekrar dönme, genişletme ve güncelleme, uygulama sonrası işlevini yitiren ölçütlerin yerine yenilerini ekleme (Dereköy, 2012, s. 55).

Bu çalışmada; Dünya Sağlık Örgütünün performans ölçüm yöntemleri, verimlilik analiz yöntemleri, maliyet-performans analiz yöntemleri, hastanelerde kullanılan dengeli ölçüm kartı ve hastane işletmelerinde kıyaslama ayrıntılı başlıklar halinde yer alacaktır.

\subsubsection{Dünya Sağlık Örgütü Performans Ölçüm Yöntemleri}

Dünya Sağlık Örgütü'nün, 2003 yılında Avrupa Ofisi önderliğinde başlatmış olduğu ve ilk olarak proje bazlı olan bu metotun öncelikli hedefi sağlık işletmelerinde performans değerlendirmesi geliştirilmesi ve esnekliğini sağlamaktır. Sunulan hizmetlerde kalite geliştirmeyi hedefleyen bu metot, hastane performans değerlendirme aracı (PATH) olarak isimlendirilmiştir. Hastane yöneticilerinin hastane hizmetlerini değerlendirmek için kullandıkları bu proje kısa dönemde ulusal veya ulusal düzeyin altında data karşılaştırmasına yardımcı olan bir yöntemdir. Orta vadede ise, veri standardizasyonuyla uluslararası karşılaştırmaların yapılmasına izin verebilmektedir (Tengilimoğlu vd., 2012, s. 396).

PATH çerçevesi toplam altı boyut ile çizilmiştir. Bunlar; klinik etkinlik, verimlilik, personel oryantasyonu, duyarlı yönetim, güvenlik ve hasta merkezliliktir.

Klinik etkinlik; teknik kalite, kanıta dayalı çalışmaları ve örgütü, sağlık kazançlarını, bireysel ve nüfusa ait sonuçları; verimlilik ise kaynakları, mali rasyoları, personel rasyolarını ve teknolojiyi içermektedir. Personel oryantasyonu; personelin sağlığı, motivasyonu, devir oranları ve işe devamsızlıkları gibi personel hakkında geniş bir bakış açısı kazandırmayı içeren ölçütleri kapsamaktadır. Duyarlı yönetim kavramı; toplum oryantasyonunu, ulaşılabilirliği, devamlılı̆̆ı, eşitliği, nüfusun taleplerindeki değişikliklere uyum kabiliyetini içermektedir. Güvenlik; hastaları, hizmet sunucuları, yapı ve süreci içine alan bir kavramdır. Son olarak hasta merkezlilik kavramı ile de hastalara karşı duyarlı olmaya vurgu yapılmaktadır. Hasta duyarlılığı kavramı içerisinde müşteri oryantasyonu, hasta tatmini ve hasta beklentileri yer almaktadır (Dereköy, 2012).

PATH projesinin çerçevesi dört basamağı içermektedir. Birinci basamak olarak motive etmek vardır; burada hasta katılımı gönüllüdür. Hastaneler için tasarlanan bu proje, tüm basamakların aktif olarak katılımını öngörmektedir. İkinci basamak olan ölçüm basamağında, PATH çerçevesi 
çekirdek bir setteki 17 göstergeye dayanmaktadır. Fakat ülkeler özel bir setteki önerilen ek göstergeleri de seçebilmektedirler. Üçüncü basamak olarak akla uygunluk yer alır ve bu; verileri iyileştirmek için ön koşuldur. Bununla birlikte kendi içlerinde bir son olmayıp, faaliyet için bir başlangıç noktasıdır. Çerçevenin son basamağında ise hareket unsuru vardır. PATH projesinin amacı, kalite geliştirme stratejilerine destek sağlamaktır ve en nihayetinde kalite geliştirme faaliyetleri üzerinde etkisi olmalıdır (Tengilimoğlu \& Toygar, 2013).

\subsubsection{Verimlilik Analiz Yöntemleri}

Sağlık kurumları elinde bulundurdukları sınırlı kaynakları en etkin biçimde kullanarak en iyi hizmeti sunmaya çalışmaktadırlar. Bu hizmet sunumunun başarıya ulaşıp ulaşmadığının göstergesi ise verimliliktir. Verimlilik genel tanımıyla mal veya hizmet üreten işletmelerin üretim sonuçlarının, üretim için kullanılan girdilere bölünmesiyle hesaplanmaktadır (Kağnıcıoğlu, Aydın, Hasgül \& Anagün, 2012, s. 45). Hastane işletmelerinde verimlilik analizlerinde en çok kullanılan yöntemler; oran analizi, regresyon analizi ve veri zarflama analizidir.

Oran analizi; sağlık kurumlarında finansal performans ölçümünde en yaygın olarak kullanılan yöntemdir. Analiz yönteminde iki değişken arasındaki ilişkinin hesaplanmasına ve sektörel oranlarla karşılaştırılmasına dayanmaktadır. Uygulama yöntemi açısından da daha kolay olması nedeniyle finansal ölçüm teknikleri içerisinde yaygın bir biçimde kullanılan performans ölçüm tekniğidir (Şahin, 1999, s. 128).

Regresyon analizi, parametrik bir yöntemdir. Parametrik yöntemlerde, analitik bir üretim fonksiyonunun geçerli olduğu varsayılmaktadır. Oran analizinde verimlilik; tek bir çıktı ve tek bir girdi ile ölçülürken, parametrik yöntemlerde ise tek bir çıktı birden fazla girdi ile ilişkili olduğu çoklu regresyon teknikleri yardımıyla ölçülmektedir. Regresyon analizinde amaç, bağımlı değişkendeki değişime neden olduğu düşünülen etkileri belirlemeye çalışmaktır (Dereköy, 2012, s. 59).

Performans ölçümünde kullanılan regresyon analizinin temelde üç sakıncası vardır. Bunlardan ilki birden çok girdi değişkenine karşılık tek bir çıktı değişkeninin kullanılmasıdır. İkincisi, en iyi performansa göre analiz yapmak yerine, ortalama performansa göre analiz yapmaktır. Üçüncüsü ise, regresyon analizinin üretilen çıktılarla bir eşitlikte girdilerin nasıl ilişkilendirildiğine dair 
parametrik bir üretim fonksiyonunun tanımlanmasını gerektirmesi ve performansı kötü olan birimleri tanımlayamamasıdır (Şahin, 1999, s. 132).

Veri zarflama analizi (VZA); farklı ölçekle ölçülmüş birden fazla girdi ve çıktının karşılaştırma yapmayı zorlaştırdığı durumlarda, karar verme birimlerinin (KVB) göreli performanslarını ölçmeyi amaçlayan doğrusal programlama tabanlı bir tekniktir. Bu yöntem karar verme birimlerinin göreli verimliliğini tahmin etmek amacıyla tasarlanmış olan parametrik olmayan bir yöntemdir. Karar verme birimlerince gözlenen girdi ve çıktıları esas alınarak göreceli teknik etkinliklerin değerlendirilmesi bu yöntemin temelini oluşturmaktadır. Burada karar verme birimlerinin karşılaştırma sürecindeki üretim fonksiyonunun yapısı çok önemlidir. Veri zarflama analizi, gözlenen karar verme birimlerinin girdi ve çıktı miktarlarına göre, en iyi üretim bileşimini baz alarak bir sınır tespit etmekte ve herhangi bir KVB'nin verimliliğini bu sınıra olan uzaklığına göre göreceli olarak analiz etmektedir.

VZA, her bir karar verme biriminin göreli verimliliğini, gözlemlenen girdi ve çıktılardan ağırlıklı çıktıların ağırlıklı girdilere oranını hesaplayarak belirlemektedir. Tüm birimlerin kendilerine etki yapacak ağırlıkları seçerek taraflı olmalarının önüne geçmek için probleme iki kısıt eklenmiştir. İlk olarak karar verme birimleri etkinlik ağırlıklarını öyle bir seçmelidir ki diğer karar verme birimlerinin ağırlıkları ölçüldüğünde \% 100'ü geçmemelidir. İkinci olarak ise; hiçbir ağırlık değeri negatif değer taşımamalıdır. Bu kısıtlara bağlı kalarak ağırlıklarını serbestçe seçebilen karar verme birimleri aslında aynı optimal ağırlıkları seçmektedir. VZA'yı üretim yapan işletmeler kullandığı gibi aynı zamanda hizmet üreten işletmeler de kullanmaktadır (Depren, 2008, s. 17-18). Bu bağlamda sağlık kurumları da var olan sınırlı kaynaklarıyla birer hizmet üreten işletmeler olması dolayısıyla VZA yöntemini yaygın olarak kullanmaktadırlar.

\subsubsection{Maliyet-Performans Analiz Yöntemleri}

Maliyet-performans analiz yöntemleri, sağlık kurumlarının tüm imkânlarıyla topluma veya bireye sunmuş olduğu ürün veya hizmetlerin planlamasında ve buna yönelik yapılan çalışmaların kontrol edilmesinde sağlık idarecilerine yardımcı olacak bir yönetsel araç olarak ifade edilmektedir. $\mathrm{Bu}$ yöntemin yapılmasının nedenleri arasında daha çok sağlık harcamalarını düşürmek, maliyetleri azaltmak, verimliliği yükseltmek ve nihai olarak ülke kalkınmasına katkıda bulunmak gibi faktörler sayılabilir. Maliyet- performans analizi ileriye dönük finansal planlamalara yardımcı olmak üzere yapılan ekonomik değerleme analizlerinden oluşmaktadır. $\mathrm{Bu}$ analiz yöntemleri 
içerisinde bazıları maliyet- fayda analizi, maliyet-yarar analizi ve maliyet etkililik analizidir (Dereköy, 2012, s. 60).

Maliyet-fayda analizi, uygun tedavi programlarının veya yöntemlerinin maliyetlerini ve bunların sonuçlarını parasal olarak değerlendiren bir yöntemdir. Maliyet-yarar analizi yöntemi, bireyin sağlığına yönelik sonuçların parasal olarak ifade edilmesini belirttiği için eleştirilmektedir. Ancak; sağlık kurumlarının tıbbi cihaz yatırım kararlarında uygulanabilirdir ve yöneticilerin kıt kaynaklarını maksimum yarar elde edebilecek şekilde kullanmalarına yardımcı olmaktadır. Maliyet etkililik analizi yöntemi ise, planlanan etkinlikleri gerçekleştirmek için farklı yöntemlerin maliyetlerini karşılaştırarak içlerindeki en iyiyi ve en etkiliyi bulmaya yarayan bir analiz tekniğidir (Ağırbaş, 2014, s. 426-427).

\subsubsection{Hastane İşletmelerinde Dengeli Puan Cetveli}

Robert Kaplan ve David Norton'un 1990'l1 yılların başlarında önerdiği bu metot işletme stratejilerini, uygulamaya yönelik amaçlarla ilişkilendirmek ve bu ilişkileri temsil eden göstergeleri izleyerek stratejilerin istenilen çıktılara ulaşıp ulaşmadığını kontrol etmek ana fikrine dayanmaktadır. Dengeli puan cetveli, finansal olan ve finansal olmayan performans ölçüm sistemlerini birleştiren ve sağlık işletmelerinin her düzeyinde çalışanları eğiten bir yaklaşımdır. Dengeli puan cetveli ölçümü, bireyin davranış yönelimini kontrol etmek ya da geçmişteki performansını değerlendirmek için değildir; bu ölçümden sağlık kurumlarının stratejisini, belirlemiş olduğu hedeflerinin gerçekleştirilmesini öğretmek ve bu kapsamda kolaylaştırmayı sağlamak için yararlanılmaktadır (Tengilimoğlu vd., 2012, s. 393).

\subsubsection{Sağlık İşletmelerinde Kıyaslama}

Kıyaslama sağlık işletmelerinin dışına bakmaya yönelik yapısal bir yaklaşımdır. Rakip sağlık kuruluşlarının mevcut durumda ne yaptıklarını gözlemektedir ve gelecekte hangi performans düzeyine ulaşacaklarına ilişkin projeksiyonlar yapmaktadır. Kıyaslama aynı zamanda bir keşfetme sürecidir. $\mathrm{Bu}$ süreç süreklidir ve rakiplerin sektördeki liderlerin süreçlerinin, hizmetlerinin ve ürünlerinin ölçülmesinde kullanılmaktadır. Genel olarak kıyaslama, dünyanın herhangi bir yerinde en iyi uygulamanın sistematik olarak incelenip, adapte edilmesi ve böylece performansın arttırılması olarak öngörülmektedir (Dereköy, 2012, s. 63-64).

\section{Sonuç ve Değerlendirme}


Sağlık kurumları veya işletmeler yaşanan hızlı değişimler ve teknolojik gelişmeler karşısında çalışanlarıyla birlikte bireysel ve örgütsel olarak belirlemiş olduğu hedefleri ve amaçları gerçekleştirmek için çalışmaktadırlar. Günümüz koşullarıyla birlikte artan talepleri karşılayabilmek için sağlık işletmelerinde yeterli donanım gerekmekte aynı zamanda çalışanların bu yönde eğilimlerini ve davranışlarını belirleyebilmek için bir performans değerlendirme yönetimi kaçınılmaz bir ihtiyaç haline gelmektedir. Bu durum alanda yeni çalışmalar yapılması gerekliliğini yaratmaktadır. Bu çalışmanın amacı; yerli literatürdeki sağlık kurumlarında performans değerlendirme yöntemleri araştırmalarının birisini yapmaktır.

Performans değerlendirme personelin eksikliğini veya fazlalığını belirleyebildiği gibi aynı zamanda faaliyetlerin sonuçlarına yönelik de bir değerlendirme yapmaktadır. Performans değerlendirme; sağlık işletmelerinin rakipleri içerisindeki konumunu belirleme, amaçlara yönelik gerçekleştirilen eylemlerin sonuçlarını görme, yöneticilerin personeli hakkında (ödüllendirme, cezalandırma vb.) karar vermeye yardımcı olma, çalışanın yaptığı işe yönelik ne kadar eğilimli olduğunu belirleme yönüyle önemli bir yöntemdir. Her işletme veya sağlık kurumu rakiplerinin önüne geçebilmek, kurum olarak daha fazla büyümek ve hizmet sunumunda belirlenen hedefleri gerçekleştirebilmek için çalışanların bu doğrultuda göstermiş oldukları gayret ve çabaları performans değerlendirme veya ölçme yöntemiyle incelemektedir. Her işletme veya sağlik kuruluşunun performans değerlendirme yöntemini kullanmadan önce hizmet türlerine göre bir takım performans göstergesi kriterleri vardır. Bu göstergeler; yapısal, süreç ve çıktı göstergeleridir. $\mathrm{Bu}$ kriterlere göre yapılan performans değerlendirmeleri vardır. Aynı zamanda bu çalışmanın literatür bölümünde detaylı olarak belirtilmiş olan çeşitli yöntemlerle de performans değerlendirmesi yapılabilmektedir.

Performans değerlendirmenin hangi yöntemlerle uygulamaya konulacağı, onun ne zaman ve niçin yapıldığı kadar önemlidir. Çünkü performans değerlendirmenin nasıl yapıldığını bilmek ve sonucunu değerlendirmek, onu daha da iyi anlamamızı sağlayabilir. Literatürde belirtmiş olan performans değerlendirme yöntemleri (Barutçil, 2015; Töre Başat, 2010; Şenturan, 2014; Tengilimoğlu vd., 2012; Tunçer, 2013) incelendiğinde standart bir değerlendirme yönteminin olmadığı aşikârdır. Her işletme veya sağlık kuruluşu performans değerlendirme yöntemlerinden örgüt yapısına uygun olanı seçmesi gerekmektedir. Literatürde yer alan değerlendirme yöntemleri uygulandığında organizasyonlar içerisinde bir takım düzenlemeler ve değişiklikler yapılmaktadır. Bunlar (Davutoğlu, 2014); personel planlama, ücret-maaş yönetimi, rotasyon, iş genişletme, iş 
zenginleştirme gibi uygulamaları, sözleşme yenileme ve işten çıkarma, eğitim ihtiyacının belirlenmesi ve kariyer planlaması olarak örnek verilebilir.

Performans değerlendirme gündeme geldiğinde sağlık işletmeleri içerisinde olumsuz bir alg1 oluşmaktadır. Bu olumsuz algının kırılması için öncelikle çalışanların tam katılımı sağlanmalı, süreç ile ilgili bilgiler verilmeli ve personelin aklında performans değerlendirme uygulamasına yönelik soru işareti kalmamalıdır. Bu sayede çalışanların hem performansını hem de verimlilik düzeylerini arttırmaya yönelik ilk adım atılmış olmaktadır. Performans değerlendirme gerçekleştirilen eyleme göre zamanı iyi ayarlanmalıdır. Sağlık işletmelerinin performans değerlendirme faaliyet sonucu raporu olduğu için değerlendirmenin yapıldığg zaman dilimi de bir o kadar önemlidir.

Performans değerlendirmenin yararlarından bir diğeri de çalışanın işe yatkınlığını değerlendirme ve elde edilen sonuca göre çalışanın görev ve sorumluluğunu belirlemedir. Sağl1k kurumlarında veya diğer işletmelerde çalışanlara uygun olan performans değerlendirme yöntemi bir değerlendirme uzmanı tarafından tespit edilmeli ve uygulanmalıdır. Değerlendirme sonuçları üst düzey yöneticilere rapor edilmeli ve belirlenen amaçlar doğrultusunda sağlık kurumunun veya işletmenin hareket tarzı belirlenmelidir. Sağlık hizmetine artan talep ama buna karşın mevcut kaynakların sınırlı olması çalışanların aşırı yoğunluktan kaynaklı olarak zaman içerisinde işte mutsuzluk hissetmesine ve verimsizliğe neden olmaktadır. Bu noktada, performans değerlendirme sayesinde çalışanları motive etmek, verimi yükseltmek ve personeli işine karşı daha dinamik tutmak mümkün olacaktır. Bunun için sağlık yöneticileri çalışanlarının performans ölçümlerini izlemeli ve gösterilen performans çıktılarını hem çalışanlar hem hizmeti alanlar açısından gözlemlemelidir.

Yaşanan hızlı değişimler ve teknolojik gelişmelerle birlikte bireylerin ihtiyaçları ve beklentilerinin de değişmesi ile hasta memnuniyeti sağlanması farklı uygulamalar gerektirecek bunlar için de uygun performans kriterlerinin sağlanması gerekecektir. Uygun performans kriterleri ve değerlendirme yöntemlerinin seçimi noktasında organizasyon yöneticilerine gerekli eğitimler verilebilir. Performans değerlendirme ve performans ölçümü yöneticilerin sıklıkla karşılaştı̆̆ sorunların başında yer almakla birlikte konu ile ilgili olarak performans ölçüm döngü şeklinde de belirtilebilir. Performans ölçüm döngüsü 5 aşamadan oluşmaktadır. Şekil 1'de görüldügüu üzere 
bunlar; stratejik planlama, gösterge oluşturma, veri ölçüm sistemi oluşturma, ölçümleri belirleme ve yönetim süreçleri ile ilgili bütünleşme aşamalarıdır (Celep, 2010).

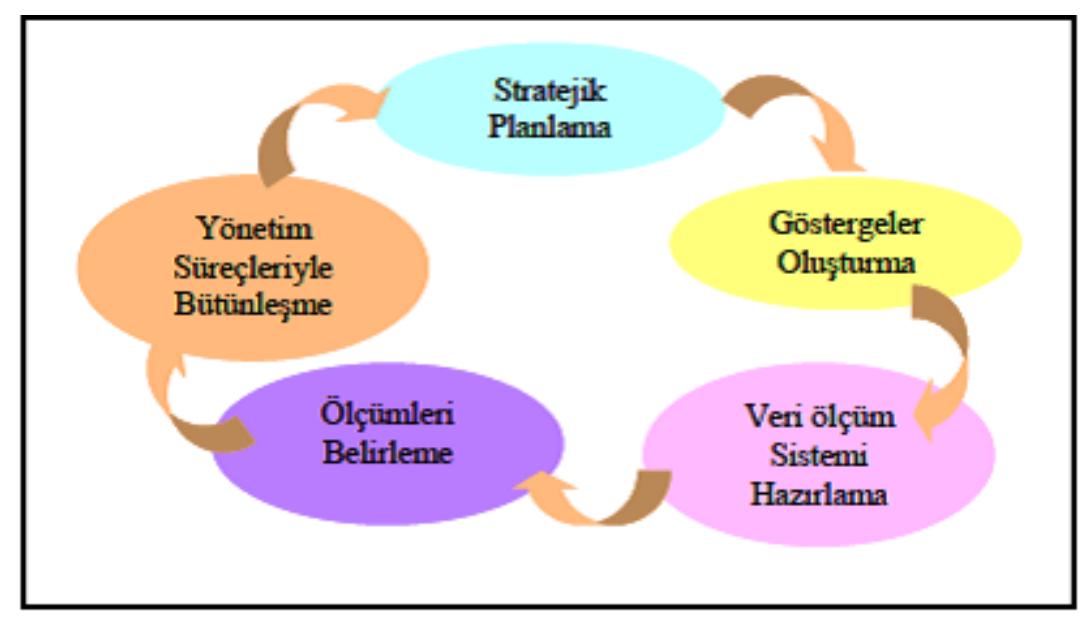

Şekil 1: Performans Ölçüm Döngüsü

Kaynak (Celep, 2010, s. 80).

Performans ölçüm döngü modelinde olduğu gibi performans değerlendirme yöntemlerinde de literatür doğrultusunda araştırmacılar tarafından uygun modeller geliştirilerek değerlendirme uzmanlarına yardımcı olunabilir. Alan araştırmacılarına, performans değerlendirme yöntemlerinin sağlık kuruluşlarına olumlu veya olumsuz getirileri üzerinde durulması gerektiği önerilebilir. Performans değerlendirmenin içeriği ile ilgili çalışanlara bilgiler verilebilir. İşgörenlere örgütün verimini arttırmaya yönelik uygulamaları kapsadığı anlatılabilir. Performans değerlendirmenin örgütün bir kısmını değil tamamını kapsadığı ve sonuçlarının tüm organizasyon yapısını etkileyebileceği ilgili yöneticilere kapsamlı eğitim programlarıyla belirtilebilir. Bu çalışmanın performans değerlendirme ve ölçüm yöntemleri ile ilgili alan yazınına katkı sağlayacağ1 düşünülmektedir. 


\section{KAYNAKÇA}

Ağırbaş, İ. (2014). Sağlık Kurumlarında Finansal Yönetim ve Maliyet Analizi. Ankara: Siyasal kitabevi.

Alparslan, D. (2014). Sağlık Bakanlı̆̆ı Hastanelerinde İşletme Sermayesi İle Finansal Performans Göstergelerinin Analizi. Süleyman Demirel Üniversitesi Sosyal Bilimler Enstitüsü. Yüksek lisans tezi. Isparta.

Appelbaum, H., David, Nadeau. \& Michael, C. (2009). Performance Evaluation İn A Matrix Organization: A Case Study (Part 3). Q Emerald Group Publishing Limited, 41(1), 9-14.

Barutçugil, İ. (2015). Performans Yönetimi. İstanbul: Kariyer Yayınları.

Bilgin, Y. \& Göral, M. (2017). Sağlık Kuruluşlarında Hizmet Kalitesinin Hasta Memnuniyetine Etkisi: Bartın Devlet Hastanesi Örneği. Bartın Üniversitesi İktisadi Ve İdari Bilimler Dergisi, 8(16), 151-176.

Celep, H. (2010). Kamu Sektöründe Performans Yönetimi ve Ölçümü. T.C. Maliye Bakanlı̆̆ Strateji Geliştirme Başkanlığı. Mesleki Yeterlilik Tezi. Ankara.

Coşkun, A. (2009). Sağlık İşletmeleri Yönetim Rehberi. Ali coşkun, Ahmet akıı (Ed.), Săgllk İşletmeleri Yönetim Rehberi içinde (s. 47-63). İstanbul: Seçkin Yayıncılık.

Davutoğlu, M. (2014). 360 Derece ve Grafik Dereceleme Performans Değerlendirme Sistemlerinin Çalışan Memnuniyetine Etkisi: Görgül Bir Araştırma. Türk Hava Kurumu Üniversitesi Sosyal Bilimler Enstitüsü. Yüksek Lisans Tezi. Ankara.

Depren, Ö. (2008). Veri Zarflama Analizi ve Bir Uygulama. Yıldız Teknik Üniversitesi Fen Bilimleri Enstitüsü. Yüksek Lisans Tezi. İstanbul.

Dereköy, F. (2012). Hastane İşletmelerinde Performans Ölçümü ve Muhasebe Bilgi Sistemi İle İlişkilendirilmesi Temelinde Bir Uygulama. Çanakkale On Sekiz Mart Üniversitesi Sosyal Bilimler Enstitüsü. Doktora Tezi. Çanakkale.

Donabedian, A. (2005). Evaluating The Quality Of Medical Care. The Milbank Quarterly, 83(4), 691-729.

Eraslan, E. \& Algün, O. (2005). İdeal Performans Değerlendirme Formu Tasarımında Analitik Hiyerarşi Yöntemi Yaklaşımı. Gazi Üniv. Müh. Mim. Fak. Der., 20(1), 95-106.

Fottler, M.D. (1987). Health Care Organizational Performance: Present And Future Research. Journal of Management, 13(2), 367- 391. 
Gün, S. (2015). Toplam Kalite Yönetimi ve Performans Değerlendirme Sisteminin İşletmeler Tarafindan Algılanma Biçimi ve Uygulanma Düzeyinin Belirlenmesi. Hasan Kalyoncu Üniversitesi Sosyal Bilimler Enstitüsü. Yüksek lisans tezi. Gaziantep.

Güner, G. (2015). Özel Hastanelerde Performans Yönetiminin Değerlendirilmesi: Ankara’ya Yönelik Bir Çalışma. Ufuk Üniversitesi Sosyal Bilimler Enstitüsü. Yüksek Lisans Tezi.

Kağnıcıoğlu, H., Aydın, S., Hasgül, S. \& Anagün, S. (2012). Üretim Yönetimi, Eskişehir, Anadolu Üniversitesi Yayını No: 2584.

Kaynak, A. (2011). Stratejik Liderliğin Performans Değerleme Üzerindeki Etkileri ve Kütahya İli Ortaöğretim Kurumlarına Ait Bir Uygulama. Dumlupınar Üniversitesi Sosyal Bilimler Enstitüsü Yayınlanmamış Yüksek Lisans Tezi. Kütahya.

Kıyak, M.T., Bozaykut, P. \& Güngör, E. (2011). Strategic Leadership Styles and Organizational Financial Performance: A Qualitative Study On Private Hospitals. 7th International Strategic Management Conference, 24, 1521-1529.

Kocabey Yaşar, M. (2014). Hemşirelerin Performans Değerlendirme Sistemi Hakkındaki Farkındalıklarının Belirlenmesi. Okan Üniversitesi Sağlık Bilimleri Enstitüsü. Yüksek Lisans Tezi. İstanbul.

Korkmaz, S. \& Çuhader, U. (2017). Sağlık Hizmet Kalitesi ve Sağlık Kurumunu Tekrar Tercih Etme Niyeti Arasındaki İlişki: Eğitim ve Araştırma Hastanesi Örneği. Uluslararası Săğlk Yönetimi ve stratejileri araştırmaları dergisi, 3(1), 72-87.

Pehlivan, B. (2008). İnsan Kaynakları Yönetiminde Performans Değerlendirmesi ve Maliye Bakanlığı Çalışanlarına Yönelik Bir Uygulama. Maliye dergisi, 154, 171-187.

Sarı, Z. (2015). Veri Zarflama Analizi ve Bir Uygulama. Hacettepe üniversitesi. Fen bilimleri enstitüsü. Yüksek lisans tezi. Ankara.

Şahin, B. (1999). Sağlık Kurumlarında Göreceli Verimlilik Ölçümü: Sağlık Bakanlığı Hastanelerinin İllere Göre Karşılaştırmalı Verimlilik Analizi. Amme İdare Dergisi, 32(2), 123-145.

Şenturan, Ş. (2014). Örnek Olaylarla Örgütsel Davranış. İstanbul: Beta Yayıncılık.

Tanrıverdi, H. \& Çiğdem, T. (2010). Eğitim Hastanelerinde Asistan Doktorların Klinik iş Yükleri Bakımından Performans Ölçütlerinin Karşılaştırılması. Sağllkta Performans ve Kalite Dergisi, 1, 114-136. 
Tengilimoğlu, D. \& Toygar, A.Ş. (2013). Hastane Performans Ölçümünde Path Yöntemi. Sosyal Güvenlik Dergisi, 3(1), 50-78.

Tengilimoğlu, D., Işık, O. \& Akbolat, M. (2012). Sağlık Işsletmeleri Yönetimi. Ankara: Nobel yayınlar1.

Tezcan, D., Yücel Hakan, M., Ünal Burak, U. \& Edirne, T. (2014). Üçüncü Basamak Sağlık Kuruluşlarında Hasta Memnuniyeti. Pamukkale Tıp Dergisi, 7(1):57-62.

Töre Başat, H. (2010). Performans Prizması. İstanbul: Sistem yayıncılık.

Tunçer, P. (2013). Örgütlerde Performans Değerlendirme ve Motivasyon. Sayıştay Dergisi, 88, 87- 108.

Tükel, B., Acuner, A.M., Önder, Ö.R. ve Üzgül A.(2004). Ankara Üniversitesi İbn-i Sina Hastanesinde Hasta Memnuniyeti: Genel Cerrahi Anabilim Dalı Örneği. Ankara Üniversitesi Tıp Fakültesi Mecmuas1, 57(4), 205-214. 